Stevens, S., Andrade, R., \& Page, M. (2016). Motivating young Native American students to pursue STEM learning through a culturally relevant science program. Journal of Science Education and Technology, 25(6), 947-960. doi: 10.1007/s10956-016-9629-1

Vélez-Ibáñez, C., \& Greenberg, J. (2005). Formation and transformation of funds of knowledge. In N. González, L. C. Moll, \& C. Amanti (Eds.), Funds of knowledge: Theorizing practices in households, communities, and classrooms (pp. 47-69). Mahwah, NJ: Lawrence Erlbaum.

Verdin, D., Godwin, A., \& Capobianco, B. (2016). Systematic review of the funds of knowledge framework in STEM education. School of Engineering Education Graduate Student Series. Retrieved from http://docs.lib.purdue.edu/enegs/59

\title{
Addressing the STEM Problem in Ways That Work
}

\author{
Karan Saggi \\ Claremont McKenna College
}

Let's look at two solutions that should be effective in addressing the gender issue in STEM. First, early intervention works. Scientific and mathematical learning can, and should, be integrated into early childhood learning and development. Miner et al. (2018) mention the potential of nurturing a child's interest in STEM through early education. The challenge is that it is segregated by gender biases ("early schooling differences, parental choices in encouraging child interests and hobbies, and other early reinforcement differences that are societally based"; Miner et al., 2018, p. 270). According to Gunderson, Ramirez, Levine, and Beilock (2012) parents tend to expect that their boys are more gifted in STEM than their girls, even when their achievement levels do not differ objectively. The focus needs to shift from moving along with this gender bias to constructively using the gender difference.

Recognizing researched gender differences and incorporating them into early education can help understand how nurture can affect STEM learning and appetite. Henderlong and Lepper (2007) find that for girls, praising the product or the process of learning may be more beneficial in boosting motivation than praising the person. A change in the approach to praise can make or break motivation. For instance, "That's a great chart" may work better than "You're so smart." Doing the opposite can flatline motivation. Bronson and Merryman (2011) also seek out gender differences in nurturing and education. Dweck (2000) highlights that an "emphasis on challenge, effort, and

Karan Saggi, Kravis Leadership Institute, Claremont McKenna College.

Correspondence concerning this article should be addressed to Karan Saggi, Kravis Leadership Institute, Claremont McKenna College, 850 Columbia Avenue, Claremont, CA 91711. E-mail: ksaggi14@cmc.edu 
strategy is absolutely essential for girls" (pp. 124-125). This praise-style ties back into the authors' referencing STEM as the discipline where "skill and merit solely determine success" (Miner et al., 2018, p. 274).

Second, we should restructure higher education to welcome women's interest in STEM. At Harvey Mudd College (HMC), the ratio of women in computer science increased from $10 \%$ to $40 \%$ in 5 years (Xia, 2017). As of January 2017, 55\% of computer science graduates were women. These statistics shine in our efforts to attract more women to STEM. Maria Klawe, Harvey Mudd's president since 2006, provided insight into two ways she restructured STEM classes.

Her approach to STEM looks at the end product: problem solving in the real world. She reports that "If the way you teach your introductory computer science course is all about the intrinsics of programming language and algorithms and computer logic and those kinds of things, and if you focus just very much on one of the technical issues, it's going to be much less appealing to young women" (Seth \& Kraft, 2017). Instead, she approaches class material as "writing a program to show how you would detect the spread of disease." In addition to appealing to more women, this approach is also reflective of the real world applications of STEM and having a gender balance in global institutions that deploy these agendas. Further, Klawe revamped the introductory course at HMC by segregating students based on prior knowledge of the material in order to eliminate any sense of intimidation to new learners. In addressing this issue on a broader scale, we can test the feasibility and potential of these two ideas in middle school and high school education as well.

Addressing "our" problem calls for parents and educators to take action through an individual lens. The social-structural lens can shift to a more neutral gender balance as well, once steps such as these are put into action and scaled.

\section{References}

Bronson, P., \& Merryman, A. (2011). NurtureShock. New York, NY: Random House.

Dweck, C. (2000). Self-theories: Their role in motivation, personality and development. Hove, UK: Psychology Press.

Gunderson, E. A., Ramirez, G., Levine, S. C., \& Beilock, S. L. (2012). The role of parents and teachers in the development of gender related math attitudes. Sex Roles, 66, 153-166. doi: 10.1007/ s11199011-9996-2

Henderlong Corpus, J., \& Lepper, M. R. (2007). The effects of person versus performance praise on children's motivation: Gender and age as moderating factors. Educational Psychology, 27(4), 487508.

Miner, K. N., Walker, J. M., Bergman, M. E., Jean, V. A., Carter-Sowell, A., January, S. C., \& Kanaus, C. (2018). From "her" problem to "our" problem: Using an individual lens versus a social-structural lens to understand gender inequity in STEM. Industrial and Organizational Psychology: Perspectives on Science and Practice, 11(2), 267-290. 
Seth, K., and Kraft, A. (Host). (2017, April 15). We're back! Let's catchup and talk to Dr. Klawe from Harvey Mudd. Diversity Sauce [Audio podcast]. Retrieved from https://www.joinkidmap.org/ diversitysauce/2017/4/28/interview-with-dr-maria-klawe-president-of-harvey-mudd-college

Xia, R. (2017, January 24). Most computer science majors in the U.S. are men. Not so at Harvey Mudd. LA Times. Retrieved from http://beta.latimes.com/local/lanow/la-me-ln-harvey-mudd-techwomen-adv-snap-story.html

\section{Developing Leaders to Tackle "Our" Problem}

Cathleen Clerkin and Marian N. Ruderman

Center for Creative Leadership

Miner et al. (2018) make a compelling argument for the need to examine gender inequity in STEM from a social-structural lens. We completely agree. We also commend the authors for including practical recommendations for industrial and organizational (I-O) psychologists, as such implementation plans are vital if we are to move this issue from theory to practice. However, while the recommendations put forth by the authors are needed, we believe additional approaches are necessary to create marked change in gender parity in STEM. In particular, we propose that I-O psychologists (along with human resource $[\mathrm{HR}]$ professionals) need to actively engage organizational leaders if we want to successfully advance more women in STEM fields.

If we accept that gender disparity in STEM is largely due to socialstructural forces, we must also accept the need to shift these forces within organizations if we desire sustained improvement. To change the beliefs and practices of everyone in organizations, we must start with leaders. Leaders have the power, authority, and resources to influence interpersonal interactions and organizational norms. Research has demonstrated that leaders set the tone when it comes to everything from ethics (Huhtala, Kangas, Lämsä, \& Fedlt, 2013) to learning and innovation (García-Morales, JiménezBarrionuevo, \& Gutiérrez-Gutiérrez, 2012). Valerio and Sawyer (2016) have shown that leaders can also set the tone when it comes to gender equity. Given this, we believe that leaders play a critical role in modeling, supporting, advocating, and sustaining gender parity practices in STEM work environments.

A core challenge for I-O psychologists is to facilitate getting STEM leaders involved in understanding and acting on "our" problem of gender

Cathleen Clerkin, Center for Creative Leadership; Marian N. Ruderman, Center for Creative Leadership.

Correspondence concerning this article should be addressed to Cathleen Clerkin, Center for Creative Leadership, 1 Leadership Place, Greensboro, NC 27438. E-mail: clerkinc@ccl.org 